\title{
SOCIAL BENEFIT OF GREEN SPACES TO LOCAL COMMUNITY
}

Gintarė VAZNONIENĖ, Business and Rural Development Management Institute, Aleksandras Stulginskis University, Universitetas str. 10-408, Akademija, Kaunas distr.; email: gintarej@gmail.com (corresponding author)

Bernardas VAZNONIS, Institute of Economics, Accounting and Finance, Aleksandras Stulginskis University, Universitetas str. 10426, Akademija, Kaunas distr.; email: bernardasv@ gmail.com

\begin{abstract}
The article deals with the concept of green spaces by highlighting its social benefit to the local community. Green spaces have become an important element in shaping rural and urban public spaces, creating attractive living surrounding, promoting integration, interaction and participation of locals, strengthening their health and enhancing overall wellbeing. Moreover, green spaces are often characterized as public spaces, so the interest in this topic implies that being in or using these spaces influences various social groups in any community. Unfortunately, the emphasis of social benefit of green spaces on the local level still lacks solid grounds in the social science discourse in Lithuania. In view of the above, the research methodology includes both theoretical and empirical research methods, where the following scientific problem is addressed: the ways or forms that the social benefit of green spaces manifests itself in relation to local communities? The aim of the research is to analyse manifestation of social benefit of green spaces to local community. The results of scientific literature analysis and interview with the specialists have provided some common insights such as how social benefit of green spaces can manifest itself on the local level. It has been acknowledged that, in terms of social benefit, green spaces are multifunctional, with their main purpose, however, being satisfaction of the needs of local community needs at the place they live in. Although green spaces are not fitted enough to support active participation, awareness of the variety of existing green spaces may contribute to promotion of various local community activities, interaction between different social groups, and appears as a "social bridge", influencing overall wellbeing of individuals and community.
\end{abstract}

Keywords: green spaces, social benefit, local community.

\section{INTRODUCTION}

It has been increasingly recognized in the scientific literature, reports on practical studies, and respective governmental policies that nature is good for our wellbeing, for present and future generations. The concept of green infrastructure characterising the importance of green spaces for society has been increasingly analysed and discussed both by environmentalists and environmental policy makers, and is becoming an important research object in social sciences. Perception of social benefit of green spaces to the entire society and to individual social groups is not a common research object in works by Lithuanian researchers. A lot of authors refer to green spaces as nature in discussion of its use by people. In this paper, the focus on green spaces is placed from the perspective of making place for public (or social) spaces, such as parks, pathways, walkways, pinewoods etc. that are open and accessible to everyone, irrespective of gender, race, ethnicity, age, or socioeconomic level. Space is organized into places, often thought of as bounded settings in which social relations and identity are constituted (Cilliers, Timmermans, 2014). Increasingly more attention is drawn to synergies between green spaces and residents as well possible resulting effects: potential benefit or damage. Researchers (Hansen, Pauleit, 2014; Mensah et al., 2016) have acknowledged that green spaces are multidimensional and provide diverse benefits to the society (economic, social, ecological, environmental etc.), meaning that multifunctionality of green spaces manifests itself by performance of "more than one" function, and benefit of green spaces is analysed in different contexts.

The rationale behind novelty and relevance of the article is presence of only few cases where social benefit of green spaces, in particular, as the opportunity to strengthen its importance local community, is analysed. The article is limited to the multidimensional concept of green spaces and focuses on identification of their social benefit, i.e. how green spaces may contribute to local community, at the same time preserving and not damaging any natural resources.

In view of the above, the research methodology includes both theoretical and empirical research methods for addressing the following scientific problem: in what ways or forms that social benefit of green spaces manifests itself in relation to local communities? The object of the research: social benefit of green spaces. The aim of the research is to analyse manifestation of social benefit of green spaces to local community. The aim is reached by performing the

Copyright (C) 2017 The Authors. Published by Aleksandras Stulginskis University. This is an open-access article distributed under the terms of the Creative Commons Attribution License (CC-BY 4.0), which permits unrestricted use, distribution, and reproduction in any medium, provided the original author and source are credited. 
following research tasks: 1) to disclose the concept of green space and its benefit; 2) to substantiate social benefit of green spaces to local community.

The article is divided into several sections and given as follows: first, theoretical description of green spaces is provided by adopting different scientific approaches to its benefit; second, research methodology is presented; finally, the research results are disclosed.

\section{THEORETICAL BACKGROUND}

\section{Conceptualisation of green spaces and their social benefit}

The concept of green spaces is multidimensional. Definition of green spaces in different sciences depends on researchers' goals, activities, and areas of interest. Green spaces are often viewed as being identical to elements of sustainable environment (environmental protection), ecology, aspects of ecosystems, where the greatest attention is given to rational use and preservation of natural resources. In order to build more extensive understanding of what green spaces are and what they cover, various researchers' insights on definitions of green spaces should be analysed.

The concept of green space, whether connected or not, should be seen as providing facilities or services for the people who live amongst it (Forest Research, 2010). Green space refers to the green places that provide specific function to communities. It recognises the environmentally beneficial role that green spaces may offer, as well as the social, economic and psychological or health benefits (Cilliers, 2015). According to Swanwick et al. (2003) and Mensah et al. (2016), green spaces cover soft land surfaces and can take the form of a liner feature (e.g. trees along transport routes), semi-natural (wetlands, woodland), functional (allotments, churchyards, school grounds), and amenity (parks and gardens) features. Hence, this means that both green and grey spaces together constitute urban or rural open spaces, with those having public access classified as public open spaces. Green spaces are also called public spaces which are regarded as democratic because everybody can use them: places that, rhetorically at least, allow "community" to exist and flourish (Communication..., 2013). As presented in Figure 1, green spaces are also natural or semi-natural (created by man) elements (The Multifunctionality..., 2012; Natural environment..., 2014) related to people's mundane lives: parks, streets, garden squares, yards, pine forests, forests, walking trails, natural monuments, playgrounds, architectural structural, etc. Green spaces differ only in terms their use or functions attributed to them; however, all green spaces have been noticed to share fairly common characteristics.

\begin{tabular}{|c|c|}
\hline $\begin{array}{l}\text { EXAMPLES OF GREEN SPACES IN } \\
\text { THEORETICAL LEVEL } \\
\text { (Benedict, McMahon, 2006; Mell, 2010; The } \\
\text { Multifuncionality..., 2012; Natural..., 2014): }\end{array}$ & $\begin{array}{l}\text { FEATURES / CHARACTERISTICS USUALLY } \\
\text { TYPICAL TO GREEN SPACES: }\end{array}$ \\
\hline $\begin{array}{ll}\text { Open countryside, } & \text { community forests, } \\
\text { parks, } & \text { woodlands, } \\
\text { waterways, } & \text { walking trails, } \\
\text { gardens, } & \text { natural monuments, } \\
\text { streets, } & \text { playgrounds, } \\
\text { green corridors, } & \text { architectural structures, } \\
\text { garden squares, } & \text { allotments etc. } \\
\text { shared yards, } & \\
\text { school yards, } & \end{array}$ & $\begin{array}{l}\text { - natural and semi-natural (man influenced) green } \\
\text { infrastructure elements, } \\
\text { - natural spaces, } \\
\text { - } \text { environment as a social space, place of interaction, } \\
\text { - } \text { natic space/open space related to humans' daily life, } \\
\text { - green recreation zones, } \\
\text { - neutral ground for different groups to come together, } \\
\text { - social green surrounding, } \\
\text { - } \text { outdoor space, } \\
\text { safe place, etc. }\end{array}$ \\
\hline
\end{tabular}

Figure 1. Theoretical examples and features (characteristics) of green spaces (made by authors)

In the view of the above, green spaces may even represent a network of various natural spaces which can be used for satisfaction of human needs and their activities. They obviously not only shape the living surroundings, encourage fostering of the surrounding nature, but also demonstrate the goods, services that could be generated from green spaces. The presented definitions reveal that a human, community and entire society perform a particular role and are responsible for use and preservation of natural resources. On the other hand, green spaces obviously are a part of human's mundane life, and use of green spaces is not always given due credit, as these are the surroundings people live in, use, etc.

In the scientific literature and various practical studies (Benedict, McMahon, 2006; Green infrastructure..., 2011), green spaces have been noted to potentially provide various benefits applicable to different contexts: economic benefits, social benefits, environmental benefits, land regeneration benefits, hydrological benefits, and ecological benefits. In terms of use of green spaces for environmental, economic, social goals, it has been observed that green spaces should be accessible and used on an individual level, as well as community, regional, national or international levels. Findings of the studies mentioned above emphasize mutual benefit for green spaces and people that manifests itself in fostering and preservation of ecosystems. In view of the variety of approaches towards green spaces, green space value could be claimed to be quite complex and significant in different contexts.

When analysing social benefit of green spaces, it is important to understand how it manifests itself. It has been acknowledged in the scientific literature (The Value..., 2010; M'Ikiugu et al., 2012) that social benefit of green spaces is 
primarily related to addressing various human needs. Green spaces form preconditions for satisfaction of not only primary, but also secondary needs related to human self-expression, assurance of participation, enhancement of the sense of fullyfledged member of society. A multitude of scientific studies based on green spaces allow to identify their social benefit to local community referred to in the scientific literature the most frequently (Table 1).

Besides the main social benefit to local community that is referred to the most frequently and highlighted in the Table, certain authors (Benedict, McMahon, 2006; M'Ikiugu et. al., 2012; Kramer, 2014) elaborate the benefit even more:

- $\quad$ proper use of green spaces creates conditions for promotion of employment within the community;

- helps form an attractive living environment;

- $\quad$ promotes environmental wellbeing;

- environmental education by promoting learning about nature through education, pupil excursions, cooperation between researchers in the area of green spaces;

- promotion of recreational, outdoor activities (promotion of outdoor sports, walking, horseback riding, relaxation);

- fostering of cultural and historic heritage among different generations of residents;

- creation of an aesthetic image;

- $\quad$ public infrastructure cost reduction (e.g., restriction of vehicle traffic by replacing it with pedestrian traffic);

- $\quad$ possibility to breathe fresh air and have access to proper drinking water;

- promotion of rural-urban integration relations;

- $\quad$ increase in real estate value;

- $\quad$ promotion of tourism, etc.

Table 1. Theoretical approaches to social benefit of green spaces (made by authors)

\begin{tabular}{|c|c|c|c|c|c|c|c|c|c|c|}
\hline $\begin{array}{r}\text { Expression } \\
\text { of social } \\
\text { benefit }\end{array}$ & 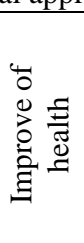 & 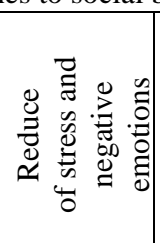 & 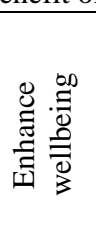 & 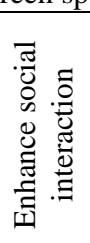 & 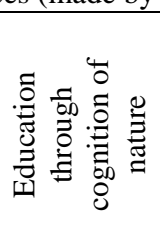 & 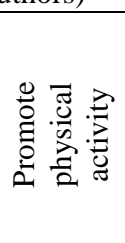 & 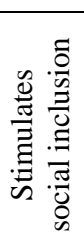 & 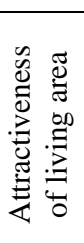 & 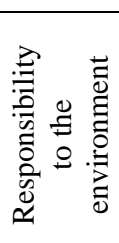 & 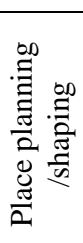 \\
\hline $\begin{array}{l}\text { Cornell et al. } \\
\text { (2001) }\end{array}$ & & & & + & + & + & + & & & \\
\hline $\begin{array}{l}\text { Galloway } \\
(2006)\end{array}$ & & & + & + & + & & + & & & \\
\hline $\begin{array}{l}\text { Cutter- } \\
\text { MacKenzie } \\
(2009)\end{array}$ & & & & + & + & & + & & & \\
\hline $\begin{array}{l}\text { Fan et al. } \\
\text { (2011) }\end{array}$ & & + & & + & & + & & & & \\
\hline $\begin{array}{l}\text { Mwendwa, } \\
\text { Giliba (2012) }\end{array}$ & + & + & + & + & & & + & & & \\
\hline $\begin{array}{l}\text { Cilliers, } \\
\text { Timmermans } \\
(2014) \\
\end{array}$ & & & & & & & & + & & + \\
\hline $\begin{array}{l}\text { Kemperman, } \\
\text { Timmermans } \\
(2014)\end{array}$ & + & & + & + & & & + & & + & + \\
\hline $\begin{array}{l}\text { Mensah et al. } \\
\text { (2016) }\end{array}$ & + & + & + & + & & & & & & \\
\hline $\begin{array}{l}\text { Artmann et } \\
\text { al. (2017) }\end{array}$ & + & & & + & + & & + & + & + & + \\
\hline
\end{tabular}

It should be noted that although social benefit of green spaces is multidimensional and implies more than one level, its main purpose is to satisfy human needs at places they live in and ensure the possibility of access to green spaces. For example, in case of the youth, green spaces become the place where young people can strengthen their status of members of local community through various activities, develop their social, cognitive abilities, strengthen their health; in case of the elderly, green spaces raise the demand for calmer public spaces, where people could socialize, have a walk, etc. According to Cilliers (2015), green spaces are often perceived as a luxury, especially in rural areas that are usually in need of basic services and characterized by housing needs. Various forms of social benefit of green spaces appear differently to local communities. It depends on the kind of green spaces present in living territory, how community views, uses and protects these existing open spaces. To summarize the social aspect of green spaces, people can be claimed to be primarily responsible for preservation of green spaces through cohesive engagement of community members, participation of different generations in the joint activity by making use of the benefit provided by green spaces. It is also important to understand that local community members will be able to make use of the benefits provided by green spaces, only if they are the first to contribute to fostering of their surroundings. This principle of protecting and enhancing nature 
and its natural processes, and the benefit that human society receives from nature, should be consciously integrated into spatial planning and territorial development of rural or urban areas.

\section{RESEARCH METHODOLOGY}

Mixed methodological approach has been applied for implementation of the research, where both theoretical and empirical research methods have been used. Theoretical background of the research is focused on analysis and synthesis of scientific literature and reports of practical studies, abstraction and comparative methods. Theoretical insights about social benefit of green spaces to local community have been substantiated using the results from semi-structured interview. This method has been used with the purpose to identify how specialists understand and characterise the functions of green spaces for local people, and place-based approaches have been integrated. The criteria for selecting the specialists are the following: a) activity/interests are close to nature/environment; b) persons are enrolled directly and quite often in the interaction with local community (mainly working with the youth); c) they work with different social groups of the community. Accordingly, 12 specialists (teachers, healthcare specialist, social educator, specialist from Kuršènai state forest, sports trainer, etc.), who have agreed to take part in the research, have been selected according to the mentioned criteria. Specialists shared their knowledge and opinion on how green places influence/or could influence local community.

The semi-structured interview protocol is an instrument designed by the authors of this paper according to the authors dealing with the analysed topic as referred to above. 17 questions including identification of the green spaces used by young people and the entire community, questions asking to detail the social functions of green spaces, and questions revealing specialists' attitude towards the effect of green spaces on community wellbeing were asked. At the beginning of interview, the informants (totally 12 and encoded by S1,...S12) were introduced to the definition of green space in order for them to have general understanding about the topic. The interview was implemented in June 2017.

The territory covered by the research includes two elderships (Kuršènai rural and urban elderships), where urban eldership is surrounded with green spaces of a rural eldership. Although the research territory is rich with green places (or natural nature, public spaces) for local community, they still are used insufficiently. They largely function as nature, but not really as an instrument or factor for the wellbeing of community. The results are presented in the subsequent section.

\section{RESEARCH RESULTS}

During the interview, general situation of green spaces was discussed with the specialists in mentioned elderships. It is worth noting that their perception about the kinds of green spaces that are important to local community was almost the same. Differences appeared when they emphasized what kind of green spaces were the most important to particular social groups. According to the specialists, young generation need green spaces (playgrounds, stadium, yards etc. - this was expressed by 6 specialists) where they could have active time. Another important aspect was absence of any new, modern, attractive green spaces in the described areas - this was the most significant problem referred to in all the interviews. In terms of older members of community, almost all specialists pointed at such green spaces as pinewood, park and riverside, but, again, the need to fit these natural open spaces for community use was emphasized. Following general identification of used green spaces of local community, it was interesting to find out how specialists described social benefit (or functions) of local green spaces (Table 2) and how close their ideas were to different scientific approaches discussed above.

Table 2. Specialists' perception about social benefit of green spaces to local community

\begin{tabular}{|l|l|c|}
\hline \multicolumn{1}{|c|}{ Social benefit } & \multicolumn{1}{|c|}{ Effect to community } & $\begin{array}{c}\text { Number of } \\
\text { specialists' answers }\end{array}$ \\
\hline $\begin{array}{l}\text { - Activation of different } \\
\text { groups in the community }\end{array}$ & $\begin{array}{l}\text { By implementation of various forms of leisure activities typical to } \\
\text { separate social groups }\end{array}$ & 7 \\
\hline - Sports activities & $\begin{array}{l}\text { Help relax, being outside is a form of leisure, walking, clear your mind, } \\
\text { fulfil with positive energy, reduce negative feelings etc. }\end{array}$ & 5 \\
\hline - Environmental protection & $\begin{array}{l}\text { Improvement of the air, cleaning of nature, raises human responsibility } \\
\text { to the nature }\end{array}$ & 4 \\
\hline $\begin{array}{l}\text { - Enhancing } \\
\text { communication/social } \\
\text { interaction, social } \\
\text { integration }\end{array}$ & $\begin{array}{l}\text { Being and socialising with others - strengthening relations between } \\
\text { parents and children (strengthening family relations), being among peer } \\
\text { groups, different generations, meetings young mothers, newcomers, etc. }\end{array}$ & 11 \\
\hline - Cognition of nature & Becoming acquainted with fauna and flora; education through cognition & \\
\hline $\begin{array}{l}\text { - Health improvement (both } \\
\text { physical and mental) }\end{array}$ & Improvement of physical and mental health, reduce stress & 5 \\
\hline - Aesthetic & $\begin{array}{l}\text { Has effect on formation of public spaces, local area image, signals areas } \\
\text { that need improvement for the local government }\end{array}$ & 4 \\
\hline - Negative approach & $\begin{array}{l}\text { Not enough spaces; poorly equipped spaces; no playgrounds for } \\
\text { children, no lighting }\end{array}$ & 1 \\
\hline
\end{tabular}


As suggested by the Table above, specialists demonstrated quite different attitudes towards the social benefit of green spaces they identified in the analysed elderships. They fully agreed that the biggest positive aspect was that Kuršenai rural and urban elderships had a truly large number of open green spaces. The majority have acknowledged that interconnection between urban and rural areas is direct in terms of movement of the locals. This is primarily related to the situation where some children from rural eldership use education services in urban eldership. Second, older people travel to their jobs by foot, etc. It also cannot be neglected that facilitation of social interaction, inclusion in the community have different benefits on mental health and on different kinds of people, who usually cannot come along or may not normally agree to come together in other kinds of spaces. In this respect, there were only few individual bad opinions of the existing situation of green places, or the specialists had doubts about the long-lasting effect of green spaces. In general, it could be stated that social connectedness promoted by green spaces enables individuals to develop the sense of belonging and good interpersonal relationships with others that supports social wellbeing, which is one of the domains of quality of life.

Though green spaces have been found to provide various social benefit, the specialists' attitude towards the effect of green spaces on wellbeing of the local community and, separately, of the youth, has also been determined (Table 2). As suggested by the Table, specialists' opinions have shown that youth is just one social group in that community; however, green spaces have positive meaning to almost all groups. In their answers, most of the specialists (8 from 12) directly mentioned positive approach towards being in green spaces.

Table 2. Specialists' attitude to how green spaces affect local community and youth wellbeing

\begin{tabular}{|c|c|}
\hline How does being in green spaces affect community wellbeing? & How does being in green spaces affect youth WB? \\
\hline $\begin{array}{l}\text { - Improves wellbeing through their better behavior (S1) } \\
\text { - } \quad \text { Better/closer relations have impact on community wellbeing } \\
\text { (S2) } \\
\text { - } \quad \text { Extremely good effect of being in green spaces (S3) } \\
\text { - } \text { It has a long-lasting effect for the future health (S4) } \\
\text { - I believe boing in green spaces has only positive things (S8) }\end{array}$ & $\begin{array}{l}\text { - } \quad \text { It makes youth happier/ become more happy (S1, S3) } \\
\text { - } \quad \text { It helps to reduce stress, relax, become calm (S2) } \\
\text { - } \quad \text { Certainly it has just positive effect (S4, S5, S6, S9, S10) } \\
\text { - } \quad \text { Surely much more better than sitting nearby computer or } \\
\text { using other IT (S8) } \\
\text { - They become more friendly, helpful to others, what raises } \\
\text { their selfesteem, respect to other human (S1, S2, S7, S9) }\end{array}$ \\
\hline
\end{tabular}

It should also be noticed that bigger part of specialists have agreed that community wellbeing consists of various factors and being/using green spaces contributes to higher level of wellbeing. Only one specialist has pointed that green spaces sometimes can be used for damaging other wellbeing, e.g., when certain individuals commit crimes.

Results of the interview have demonstrated that specialists' attention is also drawn to consideration of how local government and other local actors perceive the importance of green public spaces to local community and sustainable development of nature. It has also been found that green infrastructure or green space planning needs to adopt a multiscale approach that involves not only individuals and local communities, but also various actors on the regional and state level. This idea was also tested and confirmed by several previous researchers (Cilliers, Timmermans, 2014; Artmann et al., 2017). Finally, as suggested by both the empirical research and certain foreign researchers (Fan et al., 2011; Hansen, Pauleit, 2014), the core principles of green infrastructure/green space planning are related to enhancing and maintaining green structure (as community integration, connectivity, multi-functionality) and governance processes (strategic approach, social inclusion, transdisciplinary).

\section{CONCLUSIONS AND DISCUSSION}

Green spaces conception refers to the different understanding of what is green place. The main attention is focused on environmentally beneficial role and functions of green spaces to particular area and local community. Social benefit of green spaces is multifunctional with their main purpose satisfaction of the needs of local community through various social activities, being and feeling good. It is obvious from the empirical research that although the forms of green spaces are not fitted enough to support active participation, awareness of the variety of existing green spaces may contribute to promotion of various local community activities, interaction between different social groups, and appears as a "social bridge", influencing overall wellbeing of individuals and community.

More practical approach suggests that various local community actors should be concerned with having attractable local green spaces, because it affects not only community living and their wellbeing, but also vitality of local area, social cohesion processes.

Discussion based on the analysed topic dislosed that social benefit of green spaces to local community is not deeply perceived. Even the results of specialists interview to the analysed problem was quite general, though their activities are related to nature, various activities implemented in green spaces.

\section{REFERENCES}

1. Artmann, M., Bastian, O., Grunewald, K. 2017. Using the Concepts of Green Infrastructure and Ecosystem Services to Specify Leitbilder for Compact and Green Cities-The Example of the Landscape Plan of Dresden (Germany). Sustainability, Vol. 9, 198; https://doi.org/10.3390/su9020198

2. Benedict, M.A.; Mcmahon, E.T. 2006. Green infrastructure: Linking landscapes and communities. Island Press, Washington. 
3. Capaldi, C.A., Dopko, R.L., Zelenski, J.M. 2014. The relationship between nature connectedness and happiness: A meta-analysis. Frontiers in Psychology, Vol. 5, 976. https://doi.org/10.3389/fpsyg.2014.00976

4. Cilliers E.J., Timmermans W. 2014. The importance of creative participatory planning in the public place-making process. Environment and Planning B. Planning and Design, Vol. 41, pp. 413-429.https://doi.org/10.1068/b39098

5. Cilliers E. J. 2015. The Importance of Planning for Green Spaces. Agriculture, Forestry and Fisheries. Special Issue: Planning for Sustainable Communities: Green-Spaces in Rural Areas. Vol. 4, No. 4-1, pp. 1-5. https://doi.org/10.11648/j.aff.s.2015040401.11

6. Communication From the Commission to the European Parliament, The Council, The European Economic and Social Committee and The Committee of The Regions Green Infrastructure (GI). 2013. Enhancing Europe's Natural Capital /* com/2013/0249 final *. Available at http://eur-lex.europa.eu/legal-content/EN/TXT/HTML/?uri=CELEX:52013DC0249\&from=EN (Accessed on $15 / 10 / 2017)$

7. Cornell, E. H., Hadley, D. C., Sterling, T. M., Chan, M. A., Boechler, P. 2001. Adventure as stimulus for cognitive development. Journal of Environmental Psychology, Vol. 21, pp. 219-231. https://doi.org/10.1006/jevp.2001.0207

8. Cutter-MacKenzie, A. 2009. Multicultural school gardens. Canadian Journal of Environmental Education, Vol 14, pp. 122-35.

9. Fan, Y., Das, K.V., Chen, Q. 2011. Neighborhood green, special support, physical activity and stress: Assessing the cumulative impact. Health \& Place, Vol. 17, pp. 1202-1211. https://doi.org/10.1016/j.healthplace.2011.08.008

10. Forest Research 2010. Benefits of green infrastructure. Report to Defra and CLG. Forest Research, Farnham.

11. Galloway, S. 2006. Quality of life and well-being: Measuring the benefits of culture and sport: A literature review. Edinburgh, Scotland: Scottish Executive Social Research.

12. Green infrastructure and territorial cohesion. 2011. The concept of green infrastructure and its integration into policies using monitoring systems. EEA Technical report. European Environment Agency. No 18/2011.

13. Hansen, R., Pauleit, S. 2014. From multifunctionality to multiple ecosystem services? A conceptual framework for multifunctionality in green infrastructure planning for urban areas. AMBIO, Vol. 43, pp. 516-529. https://doi.org/10.1007/s13280-014-0510-2

14. Kemperman, A., Timmermans, H. 2014. Green spaces in the direct living environment and social contacts of the aging population. Landscape and Urban Planning, Vol. 129, pp. 44-54. https://doi.org/10.1016/j.landurbplan.2014.05.003

15. Kramer M.G. 2014. Enhancing sustainable communities with green infrastructure. A guide to help communities better manage stormwater while achieving other environmental, public health, social, and economic benefits. U.S. Environmental Protection Agency's Office of Sustainable Communities. EPA 100-R-14-006.

16. Mell, I.C. 2010. Green infrastructure: concepts, perceptions and its use in spatial planning. Thesis submitted for the Degree of Doctor of Philosophy. School of Architecture, Planning and Landscape Newcastle University.

17. Mensah, C. A., Andres, L., Perera, U., Roji, A. 2016. Enhancing quality of life through the lens of green spaces: A systematic review approach. International Journal of Wellbeing, Vol. 6(1), pp. 142-163.

18. M'Ikiugu M.M., Qianna W., Kinoshita I. 2012. Green Infrastructure Gauge: A tool for evaluating green infrastructure inclusion in existing and future urban areas. Procedia - Social and Behavioral Sciences, Vol. 68, pp. 815-825. https://doi.org/10.1016/j.sbspro.2012.12.269

19. Mwendwa P., Giliba R.A. 2012. Benefits and Challenges of Urban Green Spaces. Chinese Journal of Population Resources and Environment, Vol. 10, Iss. 1, pp. 73-79. https://doi.org/10.1080/10042857.2012.10685062

20. Natural Environment White Paper. 2014. Implementation update report. Department for Environment Food and Rural Affairs. Available at https://www.gov.uk/government/uploads/system/uploads/attachment_data/file/286547/newp-implementationupdate-20140226.pdf (Accessed on 10/10/2017)

21. Swanwick, C., Dunnett, N., Woolley, H. 2003. Nature, role and value of green space in towns and cities: An overview. Built Environment, Vol. 29(2), pp. 94-106. https://doi.org/10.2148/benv.29.2.94.54467

22. The Multifunctionality of Green Infrastructure. 2012. Science for Environment Policy. In-depth Reports. European Commission. Available at http://ec.europa.eu/environment/nature/ecosystems/docs/Green_Infrastructure.pdf (Accessed on 22/12/2016)

23. The Value of Green Infrastructure. 2010. A Guide to Recognizing Its Economic, Environmental and Social Benefits. Center for Neighborhood Technology. Available at http://www.cnt.org/sites/default/files/publications/CNT_Value-of-GreenInfrastructure.pdf (Accessed on 20/09/2017) 